\title{
Apoptosis Induced by Ultraviolet A Exposure in the Presence of Enoxacin in HL-60 Cells
}

\author{
HARUKA SHINADA, TAKAHIRO WATANABE, KAZUHO OKUDAIRA, \\ YUMIKO IWASE, KOJI NISHI and NAGAHIKO YUMITA
}

Yokohama University of Pharmacy, Yokohama, Japan

\begin{abstract}
Background: The ultraviolet A (UVA) spectrum mainly includes the region associated with the phototoxicity of fluoroquinolone antimicrobial agents. This study investigated apoptosis induced with UVA light and enoxacin in HL-60 cells. Materials and Methods: HL-60 cells were irradiated by UVA $\left(1.1 \mathrm{~mW} / \mathrm{cm}^{2}\right)$ for $20 \mathrm{~min}$ in the presence or absence of enoxacin. The induction of apoptosis was investigated by analysing cell morphology, flow cytometry of annexin V-positive cells, DNA ladder formation, and caspase-3 activation. Results: Significant induction of apoptosis, DNA fragmentation, and caspase-3 activation were observed in cells treated with both UVA and enoxacin. UVA-induced apoptosis was significantly suppressed when NaN3, a singlet oxygen scavenger, was present. Conclusion: Apoptosis was induced by the combination of UVA and enoxacin in $H L-60$ cells, and singlet oxygen appears to play an important role in photodynamically-induced apoptosis.
\end{abstract}

Ultraviolet (UV) light from the sun is a major cause of skin carcinogenesis (1-3). UVA (320-400 nm) is the predominant UV band and reaches the earth's surface. UVA penetrates the skin more deeply than UVB, and generates reactive oxygen species (ROS), which cause oxidative damage, in both the epidermal and dermal skin layers. Studies have shown that UVA causes ROS-mediated oxidative damage to the skin through peroxidation of lipid, and oxidative damage of DNA, resulting in the formation of 8-oxoguanine $(4,5)$. Previous studies have also reported that UVA causes DNA damage through photosensitization reactions in the presence of photosensitizing compound; this may induce skin cancer.

Fluoroquinolones are widely used antibiotics that play an important role in the treatment of human and animal infections

Correspondence to: Nagahiko Yumita, Yokohama University of Pharmacy, 601, Matano-cho, Totsuka-ku, Yokohama, Kanagawa 2450066, Japan. Tel: +81 0458591300, Fax: +81 0458591301, e-mail: n.yumita@hamayaku.ac.jp

Key Words: Apoptosis, ultraviolet A, enoxacin, HL-60, reactive oxygen species, caspase- 3 .
(6). The absorption spectrum associated with the phototoxicity of fluoroquinolone antimicrobial agents mainly lies on the UVA region (7-10). The fluoroquinolones strongly inhibit bacterial DNA gyrase, and type II DNA topoisomerase in mammalian cells $(7,8,11)$. Recently, it was also shown that fluoroquinolones can act as photosensitizers when administered to UVA-irradiated experimental animals (4).

Necrosis and apoptosis are two major processes of cell death. Necrosis is a form of traumatic cell death that is most commonly induced by severe damage that causes cytoplasmic swelling and disruption of the cell membrane, leading to release of lysosomal enzymes that commonly cause an inflammatory reaction. On the other hand, apoptosis is a highly regulated and controlled death process that act as a suicide program which removes unnecessary, aged, or damaged cells (12). Cells undergoing apoptosis experience biochemical events that lead to distinct morphological characteristics, including blebbing, cell shrinkage, chromatin condensation, and nuclear fragmentation. The cells further disassemble into membraneenclosed vesicles termed apoptotic bodies that are taken up or phagocytosed and digested by neighbouring cells (13-15). One physical agent that can trigger the apoptotic process in cells is UV light. It directly damages DNA and leads to high ROS formation (16-18). Understanding the apoptosis-inducing properties of photosensitizing agents may be useful for the evaluation of not only photoallergenicity for preventing adverse effects, but also photosensitization for treating cancer (19-25).

Recently, we found that photochemically-active fluoroquinolones, such as lomefloxacin, can significantly induce apoptosis of human promyelocytic leukaemia cells when activated by UVA $(12,26,27)$.

In this study, we investigated the ability of enoxacin for apoptosis induction, which is useful in determining the extent of drug photosensitivity (28).

\section{Materials and Methods}

Chemicals. Enoxacin, sodium azide, mannitol, and superoxide dismutase (SOD) were purchased from Sigma-Aldrich (St. Louis, MO, USA). All other reagents used were of analytical grade $(2,29)$. 
Cell culture. Human promyelocytic leukaemia HL-60 cells were obtained from the Riken Gene Bank (Tokyo, Japan). Since leukemia cells are known to easily undergo apoptosis, HL-60 cells were used to determine the sensitivity of response in this experiment. Cells were maintained in RPMI 1640 medium containing 10\% heat-inactivated foetal bovine serum (Gibco BRL, Tokyo, Japan), $100 \mathrm{U} / \mathrm{ml}$ penicillin $\mathrm{G}, 100 \mu \mathrm{g} / \mathrm{ml}$ streptomycin, and $2 \mathrm{mM}$ glutamine (Sigma-Aldrich) in a humidified atmosphere of $5 \% \mathrm{CO}_{2}$ at $37^{\circ} \mathrm{C}$. When cells were in the exponential growth phase, they were used for exposure experiments. HL-60 cells were harvested and washed twice in phosphate-buffered saline (PBS; $\mathrm{pH} 7.4$ ) before UVA exposure. The HL-60 cells were then resuspended at a density of $2 \times 10^{6}$ cells $/ \mathrm{ml}$ in $2.5 \mathrm{ml}$ of serumfree RPMI 1640, and transferred into a $35 \times 10-\mathrm{mm}$ polystyrene tissue culture dish (Corning, Corning, NY, USA) for exposure to UVA Immediately before exposure, $200 \mu \mathrm{M}$ enoxacin was added to the cell suspension (30).

UVA irradiation. UVA irradiation was performed using six parallel FL20SBLB lamps (Toshiba, Tokyo, Japan) with peak emission frequency of $352 \mathrm{~nm}$. Cells were exposed at a distance of approximately $20 \mathrm{~cm}$ from the lamps. The UVA intensity was measured using a radiometer (UVR-305/365; Toshiba) that was placed at the same distance from the UVA source as the cells. The UVA irradiation dose applied throughout the 20-min exposure was $0.84 \mathrm{~J} / \mathrm{cm}^{2}$. The culture samples treated with enoxacin alone were placed in the same position for the same period as cells were exposed to UVA. After treatment, HL-60 cells were once again incubated in a humidified atmosphere of $5 \% \mathrm{CO}_{2}$ at $37^{\circ} \mathrm{C}(30,31)$ and analysed as described below.

Evaluation of apoptosis and cell damage. HL-60 cells were analysed using a phase-contrast inverted microscope (Olympus, Tokyo, Japan) under $400 \times$ magnification. The integrity of the treated cells was determined by staining the cells with Trypan blue immediately after treatment. The proportion of apoptotic cells was calculated on a glass haemocytometer as the number of unstained cells showing morphological changes divided by the total number of unstained cells (30). The integrity of intact cells was also examined immediately prior to each series of treatments, with cell suspensions exhibiting $>99 \%$ integrity being used in the experiments. The proportion of total sampled cells to intact cells before treatment was used as the baseline for the integrity determination (31).

Treated and control cells were incubated for $6 \mathrm{~h}$, harvested and collected by centrifugation at $300 \times g$ for $5 \mathrm{~min}$ at room temperature. Phosphatidylserine externalization was then evaluated by staining with Muse Annexin V and Dead Cell Assay Reagent (EMD Millipore Bioscience, Burlington, MA, USA) according to the manufacturer's instructions. Cells staining positively with 7-amino-actinomycin D (7AAD), annexin V-fluorescein isothiocyanate, or both were quantified by flow cytometry using a Muse Cell Analyzer (EMD Millipore Bioscience). The apoptotic ratio was determined from the four identified cell populations: cells not undergoing detectable apoptosis (annexin V-negative and 7-AAD-negative cells); early apoptotic cells (annexin V-positive and 7-AAD-negative cells); late apoptotic cells (annexin V-positive and 7-AAD-positive cells); and necrotic cells (annexin V-negative and 7-AAD-positive cells (32).

Electrophoretic analysis for DNA fragmentation. The cells were harvested, washed in PBS (pH 7.4), and lysed in $100 \mu \mathrm{l}$ of $0.1 \mathrm{M}$ phosphate-citrate buffer. Following lysis, the samples were centrifuged at $16,000 \times g$ for $5 \mathrm{~min}$. The supernatants were then treated with $200 \mu \mathrm{g} / \mathrm{ml}$ DNase-free RNase at $37^{\circ} \mathrm{C}$ for $1 \mathrm{~h}$, followed by $1 \mu \mathrm{g} / \mathrm{ml}$ proteinase $\mathrm{K}$ at $50^{\circ} \mathrm{C}$ for $1 \mathrm{~h}$. The samples were separated by electrophoresis on $1.5 \%(\mathrm{w} / \mathrm{v})$ agarose gels containing $1 \mu \mathrm{g} / \mathrm{ml}$ ethidium bromide. The DNA fragments (DNA ladders) were visualized using a UV transilluminator (ATTO, Tokyo, Japan). The sizes of the DNA fragments were determined by comparison to DNA molecular weight markers (100-bp DNA ladder; Invitrogen, Carlsbad, CA, USA) $(29,30)$.

Measurement of caspase-3 activity. Caspase-3 activity was assayed using the specific fluorogenic substrate, $N$-acetyl-Asp-Glu-Val-Asp7-amino-4-trifluoromethylcoumarin (Ac-DEVD-AFC; MBL, Tokyo, Japan). After incubation, treated cells were washed with $50 \mathrm{mM}$ PBS (pH 7.4) and resuspended in buffer containing $50 \mathrm{mM}$ Tris$\mathrm{HCI}$ (pH 7.4), $1 \mathrm{mM}$ ethylenediaminetetra-acetic acid, and $10 \mathrm{mM}$ ethylene glycol-bis( $\beta$-aminoethyl ether)- $N, N, N^{\prime}, N^{\prime}$-tetra-acetic acid (33). The cell lysate was then centrifuged at $800 \times g$ for $5 \mathrm{~min}$, and the supernatant was incubated with peptide substrate $(50 \mu \mathrm{M})$ at $37^{\circ} \mathrm{C}$ for $2 \mathrm{~h}$. The formation of 7-amino-4-trifluoromethylcoumarin was measured using a fluorescence spectrophotometer (F-3000; Hitachi, Tokyo, Japan) with an excitation wavelength of $400 \mathrm{~nm}$ and an emission wavelength of $505 \mathrm{~nm}$. The enzymatic activity measured immediately prior to each experiment was used as the control value. The caspase activity was expressed as the ratio of released 7-amino-4-trifluoromethylcoumarin under the experimental condition to that of the untreated control (30).

Effect of ROS scavengers. To determine whether ROS, including singlet oxygen, superoxide radicals and superoxide radicals, participate in the induction of apoptosis due to UVA combined with enoxacin, we examined the effect of ROS scavengers $\left(10 \mathrm{mM} \mathrm{NaN}_{3}, 100 \mathrm{mM}\right.$ mannitol or $100 \mu \mathrm{g} / \mathrm{ml} \mathrm{SOD)}$ on the proportion of cells exhibiting phosphatidylserine externalization by annexin V staining (30).

Statistical analysis. The results are expressed as the mean \pm standard deviation (S.D.). The values were compared by one-way analysis of variance, with $p=0.05$ as the minimum level of significance (34).

\section{Results}

Morphological changes. Apoptosis was studied by examining the morphological changes of cells using phase-contrast microscopy after a 4-h incubation period following the treatment with enoxacin alone, UVA alone, or enoxacin plus UVA (Figure 1). There were no significant morphological changes in cells treated with enoxacin alone (Figure 1B) or UVA alone (Figure 1C). In contrast, membrane blebbing and cell shrinkage were clearly observed in cells treated with enoxacin plus UVA (Figure 1D).

Induction of apoptosis. Induction of apoptosis and necrosis was measured by flow cytometry $6 \mathrm{~h}$ after treatment. Figure 2 shows representative dot charts of annexin V/7-AAD bivariate flow cytometry after a 4-h incubation period following treatment with enoxacin alone, UVA alone, or enoxacin plus UVA, or no treatment. The dot-plot histogram revealed that there was no significant induction of apoptosis 

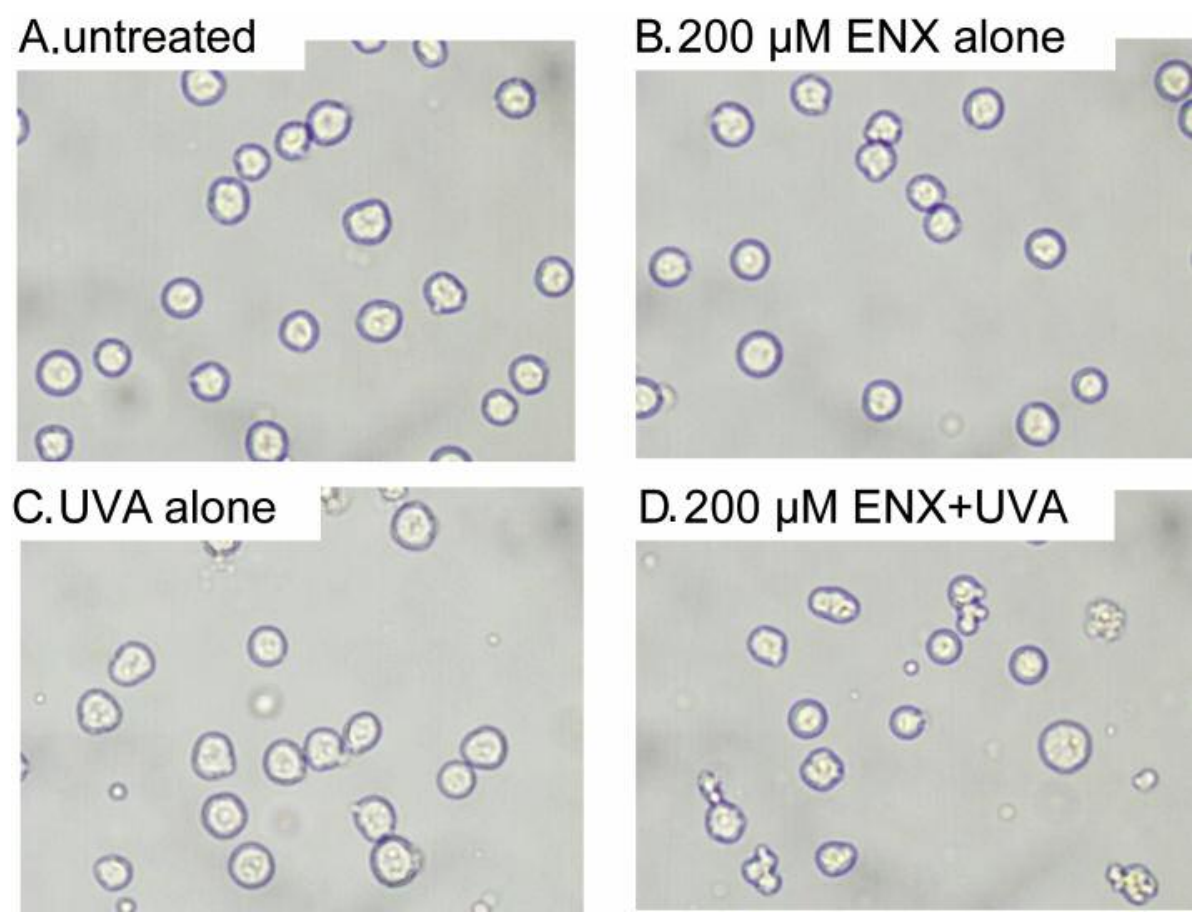

Figure 1. Analysis of cellular morphology using phase-contrast microscopy $4 \mathrm{~h}$ after no treatment (A), and treatment with $200 \mu \mathrm{M}$ enoxacin alone (B), UVA alone (C), or $200 \mu \mathrm{M}$ enoxacin $+U V A(D)$.

in cells treated with enoxacin alone (Figure 2B) or UVA alone (Figure 2C). In contrast, early apoptosis, i.e. cells positive only for annexin $\mathrm{V}$, was clearly seen in the enoxacin plus UVA-treated cells (Figure 2D).

Figure 3 shows the proportion of early apoptotic HL-60 cells over the duration of the incubation period after treatment. Under all conditions, the proportion of early apoptotic cells was less than $2 \%$ immediately following the initiation of the treatment. In cells treated with enoxacin plus UVA, there was a significant increase in the proportion of early apoptotic cells over time. HL-60 cells that were treated with enoxacin at $200 \mu \mathrm{M}$ underwent apoptosis. The proportion of early apoptotic cells reached a maximum after $4 \mathrm{~h}$, and subsequently decreased. No significant increase in the proportion of apoptotic cells was observed in cells treated with UVA or enoxacin alone.

DNA fragmentation. To further explore the mechanism of UVA-mediated apoptosis with enoxacin in these cells, agarose gel electrophoresis was performed using DNA samples from the HL-60 cells. No distinct DNA ladder was observed for cells treated with enoxacin or UVA alone (Figure 4, lanes 3 and 4, respectively). In contrast, a DNA ladder was clearly observed $4 \mathrm{~h}$ after exposure to UVA for cells treated with $200 \mu \mathrm{M}$ enoxacin with UVA (Figure 4, lanes 5 and 6 , respectively).
Caspase-3 activation. To investigate whether the activation of caspases by UVA and enoxacin lead to apoptosis of HL60 cells, the enzymatic activity of caspase- 3 was measured using a peptide substrate which becomes fluorescent when cleaved by active caspase-3 (Figure 5). We observed that caspase- 3 activity increased, peaking at $1 \mathrm{~h}$ after treatment, in cells treated with UVA in the presence of $200 \mu \mathrm{M}$ enoxacin. No increase in caspase-3 activity was observed in cells treated with UVA or enoxacin alone.

Effect of ROS scavengers. To elucidate the mechanism of apoptosis induced photodynamically, we next investigated the effect of ROS scavengers on the induction of apoptosis with UVA with/without enoxacin (Figure 6). $\mathrm{NaN}_{3}$ significantly suppressed the induction of apoptosis in cells treated with enoxacin plus UVA. In contrast, SOD and mannitol did not appear to affect the induction of apoptosis $(12,30)$.

\section{Discussion}

Firstly, we examined whether exposure to UVA in the presence of enoxacin induces apoptosis in HL-60 cells. We found that UVA-induced apoptosis was greatly enhanced by enoxacin, morphological indicators such as membrane blebbing, cell shrinkage, formation of membrane protrusions and breaking of cells into apoptotic bodies 


\section{A.untreated}

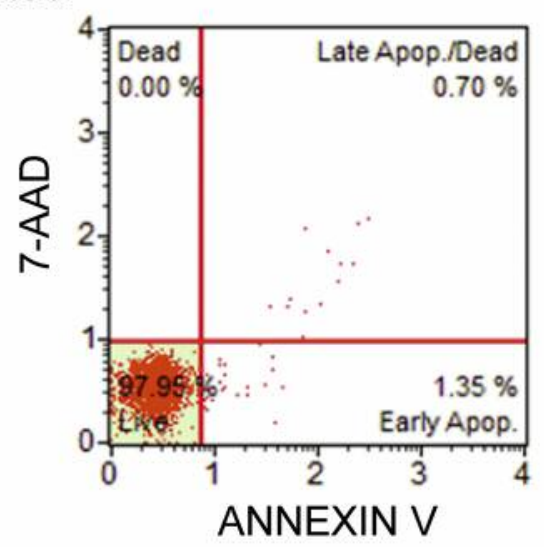

C.UVA alone

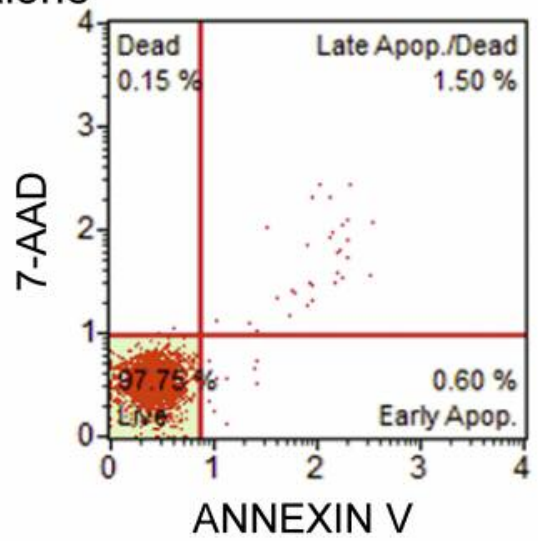

B. $200 \mu \mathrm{M}$ ENX alone

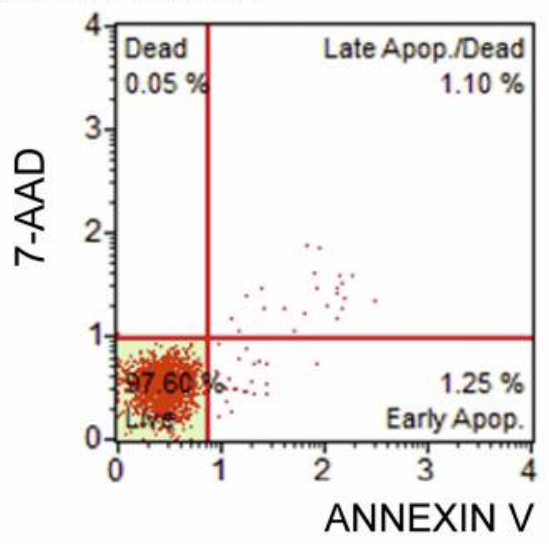

D. $200 \mu \mathrm{M} E N X+U V A$

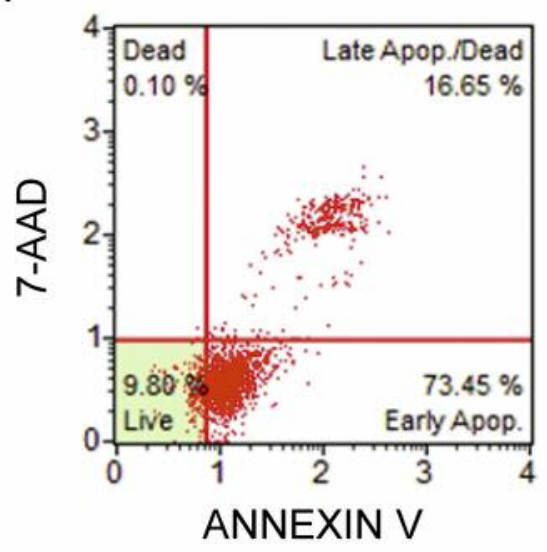

Figure 2. Representative dot charts of annexin V/7-amino-actinomycin D bivariate flow cytometry after 4-h incubation of HL-60 cells with no treatment $(A)$, and treatment with $200 \mu M$ enoxacin alone $(B), U V A$ alone $(C)$, or $200 \mu M$ enoxacin $+U V A(D)$.

were clearly observed in cells treated with both UVA and enoxacin, while no significant morphological changes were observed in cells exposed to either UVA or enoxacin alone (30). The proportion of apoptotic cells among enoxacin plus UVA-treated cells increased by more than one order of magnitude when compared to those treated with enoxacin or UVA alone. These results clearly showed the synergistic effect of enoxacin and UVA on the induction of apoptosis (30).

The fragmentation of DNA at linker regions between nucleosomes into fragments of multiples of 180-200 base pairs in length is reported to be a hallmark of apoptosis (3133). In this study, enoxacin plus UVA treatment resulted in the formation of a characteristic DNA ladder on agarose gel electrophoresis. This was not observed immediately after exposure (data not shown), but was clearly observed $4 \mathrm{~h}$ later, suggesting that the DNA fragmentation was caused by an enzymatic process rather than by photodynamic activation of enoxacin $(30,32,34)$.

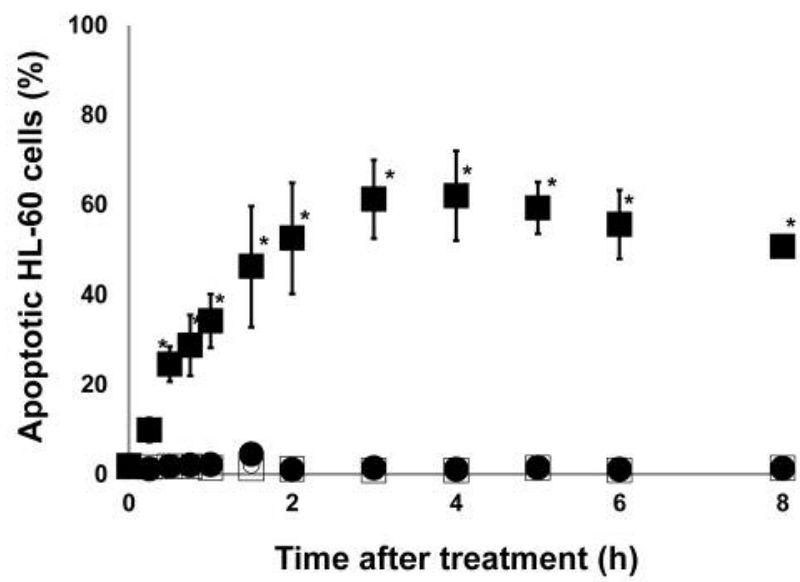

Figure 3. Proportion of apoptotic HL-60 cells following UVA exposure in the presence or absence of $200 \mu \mathrm{M}$ enoxacin. $\bigcirc$ Untreated; $200 \mu \mathrm{M}$ enoxacin alone; $\square$ UVA alone; $\square 200 \mu M$ enoxacin + UVA. Values represent the mean \pm S.D. of three independent experiments. *Significantly different at $p<0.05$ in comparison to the untreated controls. 


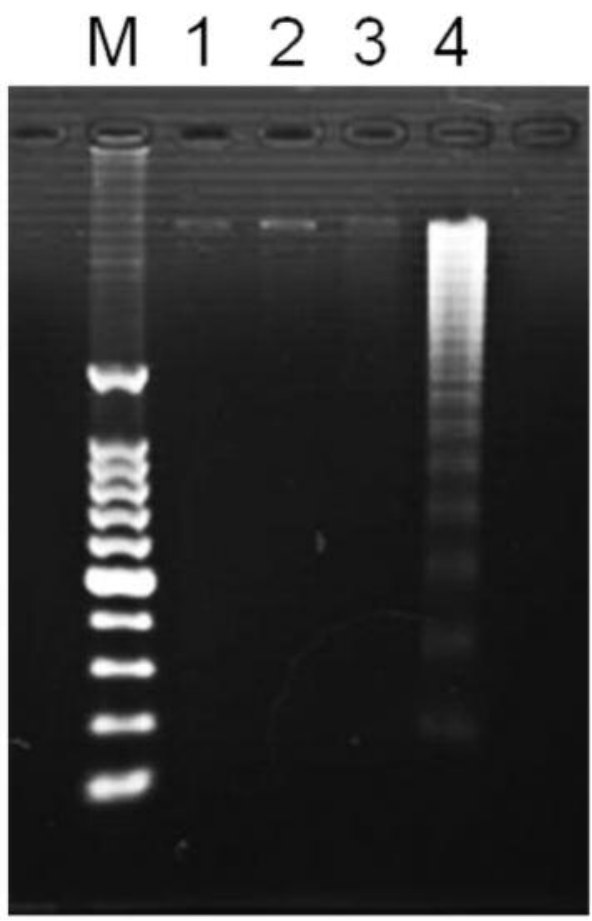

Figure 4. DNA ladder formation in HL-60 cells $4 \mathrm{~h}$ after treatment with enoxacin with and without UVA. Lane 1, DNA molecular size markers; lane 2, untreated; lane 3, $200 \mu M$ enoxacin alone; lane 4, UVA alone; lane 5, $200 \mu M$ enoxacin $+U V A$.

There are two kinds of caspases, initiator caspases and effector caspases. Caspase- 3 which is an effector caspase, is activated by active initiator caspases via proteolytic cleavage. Caspase-3 plays an important role on the execution of the final phase of apoptosis, and it is activated in cells to carry out apoptotic death (34-36). We observed significant activation of caspase-3 after treatment with enoxacin plus UVA. Both the proportion of apoptotic cells and the activity of caspase-3 gradually increased, reaching a peak $4 \mathrm{~h}$ after treatment, before subsequently decreasing, which suggests that caspase- 3 acted as the executor caspase responsible for the induction of apoptosis following the combination treatment. However, the mechanism by which caspase- 3 is activated by treatment with enoxacin plus UVA remains to be determined. Some structure-activity relationship studies have been performed for quinolone-induced phototoxicity $(4,5)$, and the results have suggested that the phototoxicity of quinolones is determined by the nature of its 8-position substituent; halogens caused the greatest photoreactive activity, while hydrogen and methoxy substituents had little effect $(34,35)$. In the pathogenesis of various skin diseases, a number of signalling pathways are activated as a result of UVA-mediated ROS generation. ROS are believed to activate proliferative and cell survival signalling that can alter the

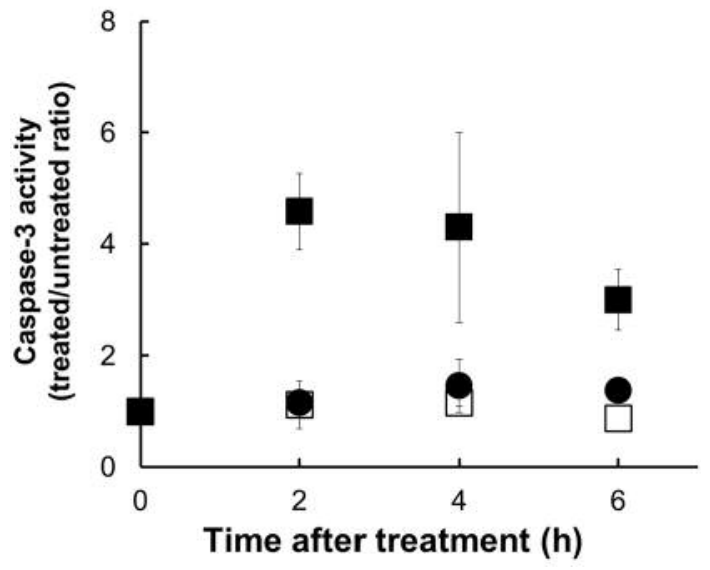

Figure 5. Caspase-3 activity in HL-60 cells following UVA exposure in the presence and absence of $200 \mu M$ enoxacin. $\square 200 \mu M$ Enoxacin alone; UVA alone; $200 \mu M$ enoxacin + UVA. Values represent the mean $\pm S . D$. of three independent experiments. ${ }^{*}$ Significantly different at $p<0.05$ in comparison to untreated controls.

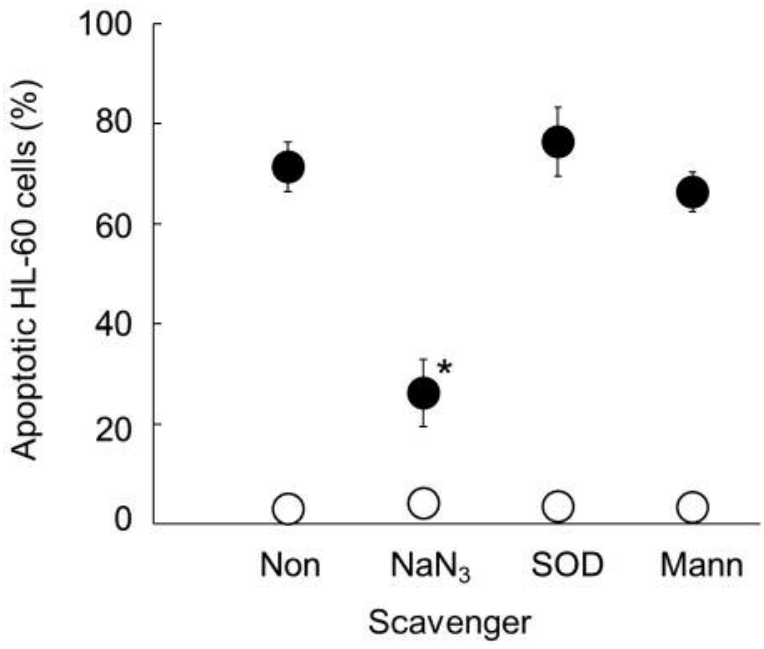

Figure 6. Effect of reactive oxygen scavengers on UVA-induced apoptosis $4 \mathrm{~h}$ after treatment in the absence $(\bigcirc)$ and presence $(\mathbf{O})$ of $200 \mu M$ enoxacin. Values represent the mean $\pm S . D$. of three independent experiments. *Significantly different at $p<0.05$ in comparison to the control cells with no scavenger (None).

apoptotic pathways involved in the pathogenesis of a number of skin disorders, including photosensitivity (30-36).

The ROS scavengers used in this study included NaN3, which is reported to be scavenger of singlet oxygen; mannitol at a concentration $(100 \mathrm{mM})$ that should scavenge photodynamically-induced hydroxyl radicals; and SOD, which catalyses the elimination of superoxide radicals (12, 37-38). $\mathrm{NaN}_{3}$ caused significant suppression of UVA- 
induced apoptosis, suggesting that singlet oxygen plays a more important role than hydroxyl radicals or superoxide in the induction of apoptosis based on the combination of UVA and enoxacin. Several mechanisms involving the generation of ROS have been proposed to explain the photodynamic action of enoxacin $(22,23)$. Activated high-energy enoxacin species are formed during the intermolecular interaction between excited enoxacin and oxygen molecules in the ground state, thereby resulting in intermolecular energy transfer and the formation of singlet oxygen, as follows:

Enoxacin (ground state) + UVA energy $\rightarrow$ enoxacin (singlet) Enoxacin (singlet) $\rightarrow$ enoxacin (triplet)

Enoxacin (triplet) $+{ }^{3} \mathrm{O}_{2}$ (triplet) $\rightarrow$ enoxacin (ground state) $+{ }^{1} \mathrm{O}_{2}$ (singlet)

The above sensitization mechanism that leads to generation of singlet oxygen is defined as a type II photoreaction (32). In the present study, a scavenger of singlet oxygen led to significant suppression of the induction of apoptosis, while scavengers of superoxide anion and hydroxyl radical did not. Our results support a previous study that suggests that singlet oxygen stimulates apoptotic cell death signalling pathways. This knowledge may lead to the establishment of new approaches for cancer therapy that utilize the formation of singlet oxygen through UVA-mediated photosensitization of enoxacin specifically targeting tumour cells $(30,31,37-52)$.

\section{References}

1 Boyer JZ, Jandova J, Janda J, Vleugels FR, Elliott DA and Sligh JE: Resveratrol-sensitized UVA induced apoptosis in human keratinocytes through mitochondrial oxidative stress and pore opening. J Photochem Photobiol B 113: 42-50, 2012.

2 Daniels F, Brophy D and Lobitz WC: Histochemical responses of human skin following ultraviolet irradiation, J Invest Dermatol 37: 351-357, 1961.

3 Tokura FY: Immune responses to photohaptens: Implications for the mechanisms of photosensitivity to exogenous agents. J Dermatol Sci 23: 6-9, 2000.

4 Hiraku Y and Kawanishi S: Distinct mechanisms of guaninespecific DNA photodamage induced by nalidixic acid and fluoroquinolone antibacterials. Arch Biochem Biophys 382: 211218, 2000.

5 Strickland PT: Photocarcinogenesis by near-ultraviolet (UVA) radiation in Sencar mice. J Invest Dermatol 87: 272-275, 1986.

6 Perucca P, Savio M, Cazzalini O, Mocchi R, Maccario C, Sommatis S, Ferraro D, Pizzala R, Pretali L, Fasani E, Albini A and Stivala LA: Structure-activity relationship and role of oxygen in the potential antitumour activity of fluoroquinolones in human epithelial cancer cells. J Photochem Photobiol B 140: 57-68, 2014.

7 Su T, Li MD, Ma J and Phillips DL: Time-resolved spectroscopic study of the defluorination and cyclization reactions of lomefloxacin in water. J Phys Chem B 121: 4512-4520, 2017.
8 Bossi O, Gartsbein M, Leitges M, Kuroki T, Grossman S and Tennenbaum T: UV irradiation increases ROS production via PKCdelta signaling in primary murine fibroblasts. J Cell Biochem 105: 194-207, 2008.

9 Appelbaum PC and Hunter PA: The fluoroquinolone antibacterials: Past, present and future perspectives. Int $\mathrm{J}$ Antimicrob Agents 16: 5-15, 2000.

10 Martínez LJ, Sik RH and Chignell CF: Fluoroquinolone antimicrobials: singlet oxygen, superoxide and phototoxicity. Photochem Photobiol 67: 399-403, 1998.

11 Shen LL, Kohlbrenner WE, Weigl D and Baranowski J: Mechanism of quinolone inhibition of DNA gyrase. Appearance of unique norfloxacin binding sites in enzyme-DNA complexes. J Biol Chem 264: 2973-2978, 1989.

12 Yumita N, Iwase Y, Nishi K, Komatsu H, Takeda K, Onodera K, Fukai T, Ikeda T, Umemura S, Okudaira $\mathrm{K}$ and Momose Y: Involvement of reactive oxygen species in sonodynamically induced apoptosis using a novel porphyrin derivative. Theranostics 2: 880-888, 2012.

13 Mustaev A, Malik M, Zhao X, Kurepina N, Luan G, Oppegard LM, Hiasa H, Marks KR, Kerns RJ, Berger JM and Drlica K: Fluoroquinolone-gyrase-DNA complexes: two modes of drug binding. J Biol Chem 289: 12300-12312, 2014.

14 Hiraku Y and Kawanishi S: Distinct mechanisms of guaninespecific DNA photodamage induced by nalidixic acid and fluoroquinolone antibacterials, Arch Biochem Biophys 382: 211$218,2000$.

15 Searle J, Kerr JF and Bisho CJ: Necrosis and apoptosis: distinct mode of cell death with fundamentally different significance. Pathol Annu 17: 229-259, 1982.

16 Jandova J, Janda J and Sligh JE: Cyclophilin 40 alters UVAinduced apoptosis and mitochondrial ROS generation in keratinocytes. Exp Cell Res 319: 750-760, 2013.

17 Kerr JF, Cooksley WG, Searle J, Halliday JW, Halliday WJ, Holder L, Roberts I, Burnett W and Powell LW: The nature of piecemeal necrosis in chronic active hepatitis. Lancet 20: 827-828, 1979.

18 Wyllie AH, Kerr JF and Currie AR: Cell death: The significance of apoptosis. Int Rev Cytol 68: 251-306, 1980.

19 Kurita M, Shimauchi T, Kobayashi M, Atarashi K, Mori K and Tokura Y: Induction of keratinocyte apoptosis by photosensitizing chemicals plus UVA. J Dermatol Sci 45: 105-12, 2007.

20 Kerr JF: History of the events leading to the formulation of the apoptosis. Toxicology 181-182: 471-474, 2002.

21 Suschek CV, Schroeder P, Aust O, Sies H, Mahotka C, Horstjann M, Ganser H, Mürtz M, Hering P, Schnorr O, Kröncke KD and Kolb-Bachofen V: The presence of nitrite during UVA irradiation protects from apoptosis. FASEB J 17: 2342-2344, 2003.

22 Yang Y, Sharma A, Sharma R, Patrick B, Singhal SS, Zimniak P, Awasthi S and Awasthi YC: Cells preconditioned with mild, transient UVA irradiation acquire resistance to oxidative stress and UVA-induced apoptosis: role of 4-hydroxynonenal in UVAmediated signaling for apoptosis. J Biol Chem 17: 41380-41388, 2003.

23 Santamaria AB, Davis DW, Nghiem DX, McConkey DJ, Ullrich SE, Kapoor M and Lozano G and Ananthaswamy HN: p53 and Fas ligand are required for psoralen and UVA-induced apoptosis in mouse epidermal cells. Cell Death Differ 9: 549-560, 2002.

24 Ibuki Y and Goto R: Phototoxicity of benzo[a]pyrene by ultraviolet A irradiation: induction of apoptosis in Jurkat cells. Environ Toxicol Pharmacol 11: 101-109, 2002. 
25 Suschek CV, Briviba K, Bruch-Gerharz D, Sies H, Kröncke KD and Kolb-Bachofen V: Even after UVA-exposure will nitric oxide protect cells from reactive oxygen intermediate-mediated apoptosis and necrosis. Cell Death Differ 8: 515-527, 2001.

26 Godar DE: Light and death: Photons and apoptosis. J Investig Dermatol Symp Proc 4: 17-23, 1999.

27 Coven TR, Walters IB, Cardinale I and Krueger JG: PUVAinduced lymphocyte apoptosis: Mechanism of action in psoriasis. Photodermatol Photoimmunol Photomed 15: 22-27, 1999.

28 Kumar PJ, Alam S, Kumar A, Jain, K, Ansari M and Manda B: Protective activity of silk sericin against UV radiation-induced skin damage by downregulating oxidative stress. ACS Appl Bio Mater 1: 2120-2132, 2018.

29 Yumita N, Han QS, and Umemura S: Sonodynamically induced apoptosis with porfimer sodium in HL-60 cells. Anticancer Drugs 18: 1149-1156, 2007.

30 Nakai S, Imaizumi T, Watanabe T, Iwase Y, Nishi K, Okudaira K, Yumita N: Photodynamically-induced apoptosis due to ultraviolet $\mathrm{A}$ in the presence of lomefloxacin in human promyelocytic leukemia cells. Anticancer Res 37: 6407-6413, 2017.

31 Iwase Y, Yumita N, Nishi K, Kuwahara H, Fukai T, Ikeda To, Chen F, Momose $\mathrm{Y}$ and Umemura S: Apoptosis induction by aluminum phthalocyanine tetrasulfonate-based sonodynamic therapy in HL-60 cells. Jpn J App Phsy 54: 07HD05, 2015.

32 Yumita N, Watanabe T, Chen FS, Momose Y and Umemura S: Induction of apoptosis by functionalized fullerene-based sonodynamic therapy in HL-60 cells. Anticancer Res 36: 2665 2674, 2016

33 Tada-Oikawa S, Oikawa S and Kawanishi S: Role of ultraviolet A-induced oxidative DNA damage in apoptosis via loss of mitochondrial membrane potential and caspase- 3 activation. Biochem Biophys Res Commun 247: 693-696, 1998.

34 Yumita N, Han QS, Kitazumi I and Umemura S: Sonodynamicallyinduced apoptosis, necrosis, and active oxygen generation by mono-L-aspartyl chlorine6. Cancer Sci 99: 166-172, 2008.

35 Umezawa N, Arakane K, Ryu A, Mashiko S, Hirobe M and Nagano T: Participation of reactive oxygen species in phototoxicity induced by quinolone antibacterial agents. Arch Biochem Biophys 342: 275-281, 1997.

36 Nishi K, Kato M, Sakurai S, Matsumoto A, Iwase Y and Yumita $\mathrm{N}$ : Enoxacin with uva irradiation induces apoptosis in the AsPC1 human pancreatic cancer cell line through ROS generation. Anticancer Res 37: 6211-6214, 2017.

37 Bickers DR and Athar M: Oxidative stress in the pathogenesis of skin disease. J. Invest Dermatol 26:2565-2575, 2006.

38 Westendorf AF, Woods JA, Korpis K, Farrer NJ, Salassa L, Robinson K, Appleyard V, Murray K, Grünert R, Thompson AM, Sadler PJ and Bednarski PJ: Trans,trans,trans[PtIV(N3)2(OH)2(py)(NH3)]: A light-activated antitumor platinum complex that kills human cancer cells by an apoptosisindependent mechanism. Mol Cancer Ther 11: 1894-1904, 2012.

39 Rosenbaum DM, Michaelson M, Batter DK, Doshi P and Kessler JA: Evidence for hypoxia-induced, programmed cell death of cultured neurons. Ann Neurol 36: 864-870, 1994
40 Walker PR and Sikorska M: New aspects of the mechanism of DNA fragmentation in apoptosis. Biochem Cell Biol 175: 287299, 1997.

41 Walker PR, LeBlanc J and Sikorska M: Evidence that DNA fragmentation in apoptosis is initiated and propagated by singlestrand breaks. Cell Death Differ 4: 506-515, 1997.

42 Inanami $\mathrm{O}$, Takahashi $\mathrm{K}$ and Kuwabara $\mathrm{M}$ : Attenuation of caspase-3-dependent apoptosis by Trolox post-treatment of Xirradiated MOLT-4 cells. Int J Radiat Biol 75: 155-163, 1999.

43 Granville DJ, Levy JG and Hunt DW: Photodynamic therapy induces caspase- 3 activation in HL-60 cells. Cell Death Differ 4: 623-628, 1997.

44 Kuzelová K, Grebenová D, Pluskalová M, Marinov I and Hrkal Z: Early apoptotic features of K562 cell death induced by 5aminolaevulinic acid-based photodynamic therapy. J Photochem Photobiol B 73: 67-78, 2004.

$45 \mathrm{Fu}$ YC, Jin XP, Wei SM, Lin HF and Kacew S: Ultraviolet radiation and reactive oxygen generation as inducers of keratinocyte apoptosis: Protective role of tea polyphenols. J Toxicol Environ Health A 61: 177-188, 2000.

46 Viola G, Fortunato E, Cecconet L, Disarò $S$ and Basso G: Induction of apoptosis in Jurkat cells by photoexcited psoralen derivatives: Implication of mitochondrial dysfunctions and caspases activation. Toxicol In Vitro 21: 211-216, 2007.

47 Davids LM, Kleemann B, Kacerovská D, Pizinger K and Kidson SH: Hypericin phototoxicity induces different modes of cell death in melanoma and human skin cells. J Photochem Photobiol B 91: 67-76, 2008 .

48 Xue C, Wu J, Lan F, Liu W, Yang X, Zeng F and Xu H: Nano titanium dioxide induces the generation of ROS and potential damage in HaCaT cells under UVA irradiation. J Nanosci Nanotechnol 10: 8500-8507, 2010.

49 Xue LY, Chiu SM and Oleinick NL: Photochemical destruction of the BCL-2 oncoprotein during photodynamic therapy with the phthalocyanine photosensitizer Pc 4. Oncogene 20: 3420-3427, 2001.

50 Ding X, Xu Q, Liu F, Zhou P, Gu Y, Zeng J, An J, Dai W and Li X: Hematoporphyrin monomethyl ether photodynamic damage on HeLa cells by means of reactive oxygen species production and cytosolic free calcium concentration elevation. Cancer Lett 216: 43-54, 2004.

51 Lai X, Ning F, Xia X, Wang D, Tang L, Hu J, Wu J, Liu J and Li X: HMME combined with green light-emitting diode irradiation results in efficient apoptosis on human tongue squamous cell carcinoma. Lasers Med Sci 30: 1941-1948, 2015.

52 Yumita $\mathrm{N}$, Okudaira $\mathrm{K}$, Momose $\mathrm{Y}$ and Umemura $\mathrm{S}$ : Sonodynamically induced apoptosis and active oxygen generation by gallium-porphyrin complex, ATX-70. Cancer Chemother Pharmacol 66: 1071-1078, 2010.

Received December 3, 2018

Revised January 17, 2019

Accepted January 22, 2019 